Cite as: Grohmann, C.H., Sawakuchi, A.O., 2013. Influence of cell size on volume calculation using digital terrain models: A case of coastal dune fields. Geomorphology. 180-181:130-136. doi:10.1016/j.geomorph.2012.09.012

\title{
Influence of cell size on volume calculation using digital terrain models: A case of coastal dune fields
}

\author{
Carlos H. Grohmann ${ }^{\mathrm{a}, *}$, André O. Sawakuchi ${ }^{\mathrm{a}}$ \\ ${ }^{a}$ Instituto de Geociências, Universidade de São Paulo \\ Rua do Lago, 562, Cidade Universitária, São Paulo, SP, 05508-080, Brazil
}

\begin{abstract}
In this work, we analyze how variation in cell size influences the volume calculated from Digital Terrain Models (DTMs) derived from a LiDAR (Light Detection and Ranging) survey in two coastal Late Holocene dune fields in southern Brazil. Cell size varied from 1 to $100 \mathrm{~m}$. The RMSE (Root Mean Square Error) of the resampled DTMs from the original LiDAR (with 0.5 $\mathrm{m}$ resolution) increases linearly with cell size, while the R-squared decreases following a secondorder trend. The volume does not show simple linear or exponential behavior, but fluctuates with positive and negative deviations from the original DTM. This fluctuation can be explained by a random factor in the position of the cell with regard to landforms and a relationship between cell and landform size, wherein a small change in cell size can lead to an under- or overestimation of volume. ASTER GDEM (Global Digital Elevation Model) and X-SAR SRTM (Shuttle Radar Topography Mission) 1 arcsec Digital Elevation Models (DEMs) were not considered viable volume sources due to large deviations from the reference data, either as a consequence of noise in the SRTM X-SAR data or lack of bias elevation correction to a common reference base in the GDEM processing chain. Volumes from a 3 -arcsec SIR-C SRTM deviated around $\pm 5 \%$ from the reference data and are considered suitable input for numerical simulations of Quaternary dune field evolution models because these values should be within the expected range of sediment volume changes over hundreds to millions of years.
\end{abstract}

Keywords: Coastal dune field, Quaternary, LiDAR, SRTM, X-SAR, SIR-C, ASTER GDEM

\footnotetext{
* Corresponding author

Email addresses: guano@usp.br (Carlos H. Grohmann), aos@usp.br (André O. Sawakuchi)

$U R L$ : http://www.igc.usp.br (Carlos H. Grohmann)
} 


\section{Introduction}

Volume calculation from Digital Elevation Models (DEMs) or Digital Terrain Models (DTMs) ${ }^{1}$ is a very important tool in the study of Quaternary landforms. Aeolian dune fields stand out as widespread landforms occurring in wet to dry depositional settings (Fryberger and Dean, 1979; Short, 1988; Wang et al., 2002; Livingstone et al., 2007; Martinho et al., 2010) on Earth as well as on other planetary bodies such as Mars, Venus and Saturns moon Titan (Hayward et al., 2007; Radebaugh et al., 2008; Bourke et al., 2010; Fenton and Hayward, 2010). The sand supply for dune fields formation and growth is sensitive to shifts in wind patterns and pluviosity. Thus, changes in dune field volume and morphology can be related to climate change (Clemmensen et al., 2007; Sawakuchi et al., 2008; Tsoar et al., 2009; Singhvi et al., 2010; Levin, 2011). Despite the surface morphology of a dune field provide important information about wind patterns and sand availability, it records only the final phase of the evolution of a dune field. In a source-to-sink system approach, dune fields are reservoirs of sand supplied by other depositional systems such as a wave-dominated coastal system or a fluvial system. The volume of sand stored in a dune field depends on the sand flux through time, which is sensitive to climate change. Thus, the calculation of dune field volume combined with dating methods to determine ages of aeolian sand deposition, such as that based on cosmogenic nuclides (Vermeesch et al., 2010) or luminescence (Wintle, 1993; Lancaster, 2008), permit to obtain a more complete record of the climate variables affecting the evolution of dune fields and their coupled depositional systems. Numerical simulations play an important role in understanding the response of dune fields to climate change. In this context, numerical simulations of dune field evolution can be greatly improved if the volume of sediment within a certain area is known within an acceptable deviation from its true value.

In this work, we analyze how the spatial resolution of DTMs derived from a high-resolution LiDAR (Light Detection and Ranging) dataset influences the output of volume calculations. Given the high cost of LiDAR surveys and the large areas occupied by dune fields, it is also interesting to evaluate whether coarser-resolution DEMs, such as SRTM (Shuttle Radar Topography Mission - Farr et al., 2007) or ASTER-GDEM (ASTER Global Digital Elevation Model - Abrams et al., 2010), can be used to estimate the volume of dune fields within an acceptable deviation range. The calculation of sediment volumes using SRTM DEMs would be very useful for studying Quaternary aeolian sedimentation in Brazil, where more than two hundred dune fields are recognized (Sawakuchi, 2006; Giannini et al., 2007), as well as on a global scale.

\section{Study Area}

The study area is located in Santa Catarina State, southern Brazil (Fig. 1). This area comprises barrier-lagoon depositional systems with associated dune fields (Giannini et al., 2007). These systems evolved since the Middle Holocene during a phase of low-rate decreasing relative sea level after a highstand of around $2.5 \mathrm{~m}$ above the present sea level (Angulo et al., 2006). The Garopaba (northern sub-area) and the Itapirubá (southern sub-area) dune fields comprise unvegetated and vegetated aeolian dunes. The unvegetated dunes are represented by mostly barchanoid chains, while the vegetated ones include parabolic dunes, blowouts and foredunes (Martinho et al., 2006; Giannini et al., 2007; Hesp et al., 2007, 2009). These dune fields are a result of wind strength intensification and sand supply increase in southern Brazilian coast during the Late Holocene. The active portion of both dune fields, which are formed by undisturbed barchanoid chains, present ideal conditions for studying the relationship between cell size and volume estimation on DEMs.

\footnotetext{
${ }^{1}$ A Digital Terrain Model (DTM) represents the true (bare) ground surface, while a Digital Elevation Model (DEM) or Digital Surface Model (DSM) represents a surface that does not necessarily coincide with the ground and may depict man-made structures or vegetation canopy, as is the case with DEMs generated from optical remote sensing (e.g., ASTER GDEM) or Radar interferometry (e.g., SRTM).
} 

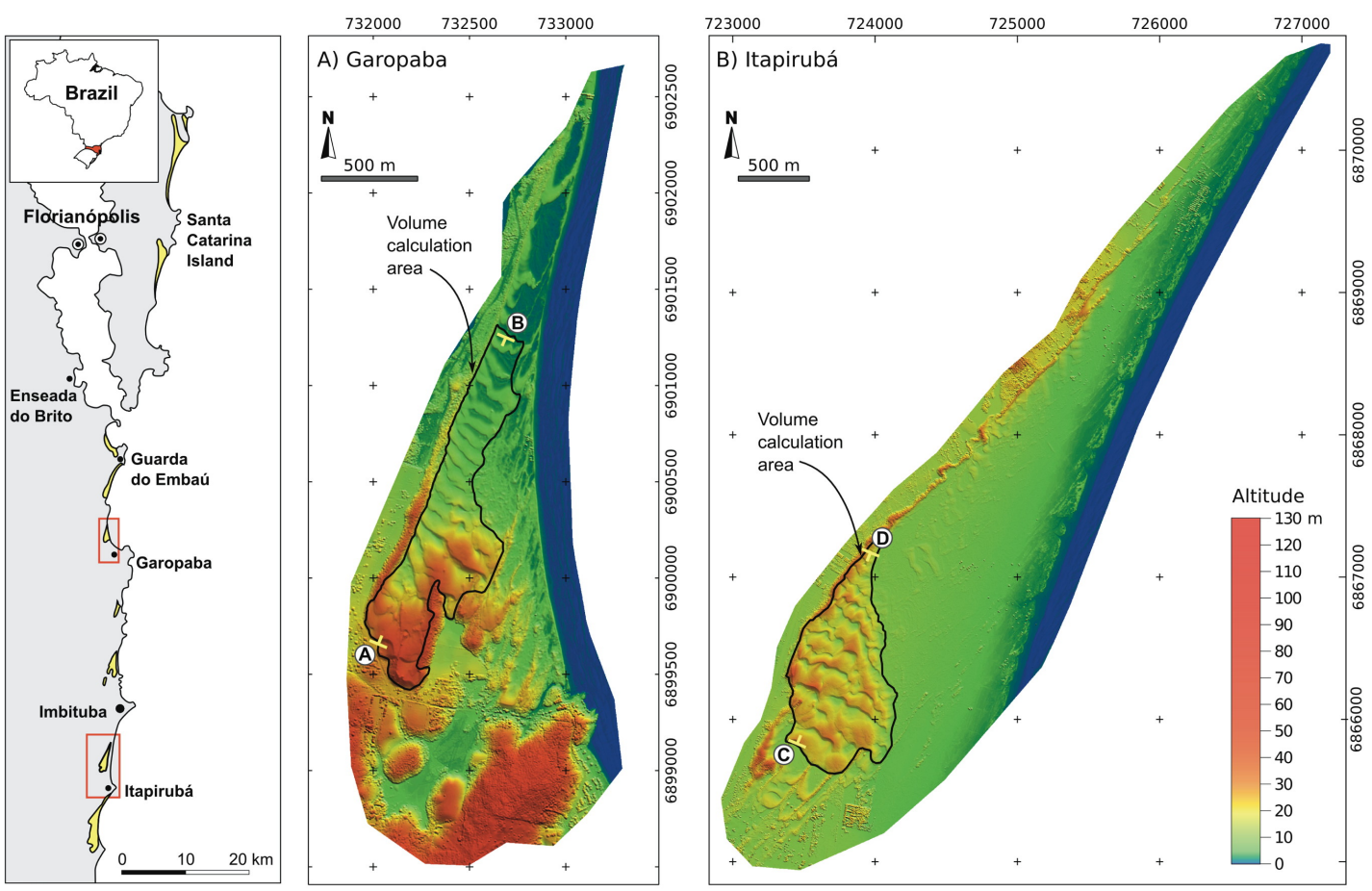

Figure 1. Location of the study area. The Garopaba (A) and Itapirubá (B) dune field DTMs are shown on the right, as well as the area selected for volume calculation and the end points of topographic profiles (A-B).

\section{Methods}

\subsection{LiDAR processing}

LiDAR data were collected on October 2010 by Geoid Laser Mapping using an Optech ALTM 3100 sensor with a saw-tooth scanning pattern, a density of about one point per $0.5 \mathrm{~m}$, measured from an altitude of $1200 \mathrm{~m}$ (4000 ft). Raw LiDAR data (with up to four laser pulses) were processed by Geoid using proprietary algorithms, and bare ground data (i.e., filtered from vegetation and man-made structures) were delivered with a vertical accuracy of $0.15 \mathrm{~m}(1 \sigma)$ and a horizontal accuracy of $0.5 \mathrm{~m}(1 \sigma)$.

Ground point data were converted to ASCII xyz points with ASPRS libLAS 1.6 (Butler et al., 2011) and imported into GRASS-GIS (Neteler and Mitasova, 2008; GRASS Development Team, 2009) as vector points. A DTM representing the ground surface with $0.5 \mathrm{~m}$ spatial resolution was created by interpolation of the vector points with bicubic splines (Brovelli and Cannata, 2004; Brovelli et al., 2004).

\subsection{SRTM and ASTER GDEM data}

To evaluate whether freely available coarser-resolution DEMs could be used to estimate the volume of dune fields within an acceptable deviation range, 3-arcsec SRTM SIR-C (Farr et al., 2007), 1-arcsec SRTM X-SAR (Eineder et al., 2001) and 1-arcsec ASTER GDEM (Earth Remote Sensing Data Analysis Center, 2009; Abrams et al., 2010) data were also imported into GRASS. Volumes were calculated with a pixel size of $90 \mathrm{~m}$ for 3 -arcsec data and $30 \mathrm{~m}$ for 1-arcsec data.

\subsection{DTM resampling and volume calculation}

To calculate the sand volume, we used the GRASS-GIS $r$.volume module (Hinthorne, 1988). This module calculates volume by summing cell values within a given area and then multiplying by the area occupied by those cells. An elevation of $0 \mathrm{~m}$ (zero) was a reference base level. Although a 
horizontal surface does not represent the true boundary of the dune field bottom surface, which can be irregular due to underlying paleotopography (Giannini et al., 2007), this should not interfere with the goals of this paper because we are interested in a comparison between volume values at different spatial resolutions. The bottom surface of aeolian dunes can be detected with geophysical methods, such as Ground Penetrating Radar (GPR). The Garopaba and Itapirubá dune fields migrate over mostly low relief $(<22.5 \mathrm{~m})$ beach ridges. The similarity between the sediments of beach ridges and aeolian dunes makes it difficult to distinguish between the two with GPR, rendering this approach impractical.

One point to consider is a DEM that has areas with positive and negative values. A negative elevation value results in a volume with negative value (sign), which will be subtracted from the positive volume when the whole DEM is processed. In this work, we are interested in sand volume deposited over the coastal area above mean sea level; therefore, we discarded any negative elevations before calculating volumes.

The 'true' volume was taken as the volume of the DTM with a $0.5 \mathrm{~m}$ resolution. To evaluate the effect of spatial resolution over volume values, the cell size varied from 1 to $100 \mathrm{~m}$, and at each step, the original DTM was resampled and the volume was calculated. Resampling was achieved by calculating the mean elevation value for a given resolution. This resampling simulates data acquired by sensors with different spatial resolutions; therefore, it is appropriate that the elevation value is the average of the actual elevations within the cell (Grohmann et al., 2010).

For each resolution step, using all cell values of the resampled DTM, we calculated the volume difference (deviation), the Root Mean Square Error (RMSE, absolute error) and the Pearson correlation coefficient (R-squared, goodness of fit) between the resampled DTM and the LiDAR DTM , where

$$
\begin{gathered}
\text { Deviation }=\left(\frac{\text { volume }_{\text {resampled }}-\text { volume }_{\text {true }}}{\text { volume }_{\text {true }}}\right) \times 100 \\
R M S E=\sqrt{\frac{\sum_{i=1}^{n}\left(z_{\text {resampled }}-z_{\text {true }}\right)^{2}}{n}}
\end{gathered}
$$

and where $z$ is the elevation for each cell and $n$ is the total number of cells.

Additionally, topographic profiles were derived from all of the models to visualize how the variation in spatial resolution would affect the representation of landforms.

\section{Results}

\subsection{LiDAR DTM}

Fig. 2 shows the calculated volume of the Garopaba and Itapirubá dune fields for each resolution step and the volume difference between the models as a percentage of error from the LiDAR DTM.

The maximum deviation in volume ranges from $\pm 5 \%$ for the Garopaba field and $\pm 4 \%$ for the Itapirubá field, with a significant high frequency alternation between positive and negative values for cell sizes above $20 \mathrm{~m}$. This result is somewhat counterintuitive, as one could expect the difference in volume to increase with cell sizes. In fact, the RSME and R-squared between the resampled models and the LiDAR DTM present such behavior with an approximate linear increase. In Fig. 3 , the left plots show a linear trend of increasing RSME values as the cell size increases, and the right plots show a decrease in R-squared values that can be fit to a second-order polynomial trend.

The linear relationship between RSME values and cell size shown in Fig. 3 should be seen as an approximation for cell sizes less than $10 \mathrm{~m}$, as the data points show non-linear behavior in this area of the plot, particularly for cell sizes under $5 \mathrm{~m}$. This is an important point for future studies, as LiDAR technology keeps evolving toward finer resolutions. 

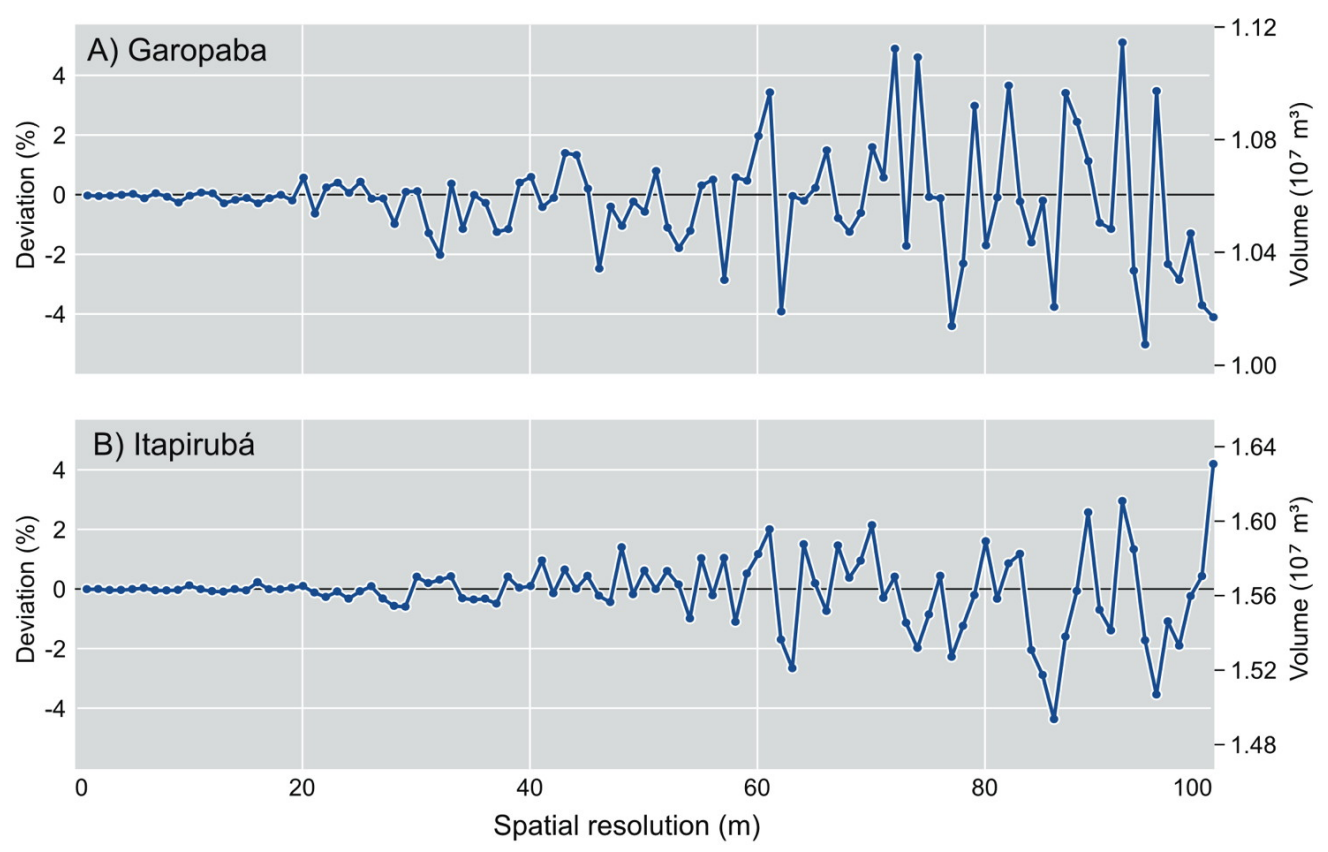

Figure 2. Volume variation with cell size and difference from the LiDAR DTM for the Garopaba (A) and Itapirubá (B) dune fields.
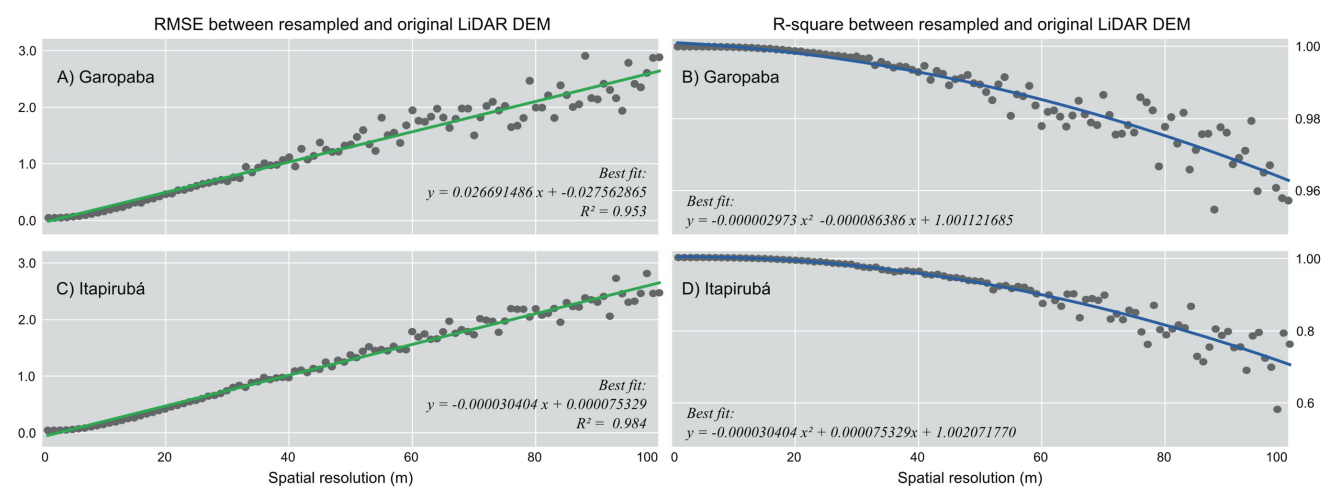

Figure 3. RSME (left) and R-squared (right) plots between resampled models and LiDAR data for the Garopaba $(A, B)$ and Itapirubá $(\mathrm{C}, \mathrm{D})$ dune fields. Thick line shows best fit of first order for RMSE values and of second order for R-squared values.

The variation between positive and negative deviations of volume can be better understood by comparing topographic profiles for each resampled DTM with a profile of the true LiDAR DTM. The profiles in Fig. 4 correspond to the central portion of the A-B profile indicated in Fig. 1. The thin black line corresponds to the profile over the true LiDAR DTM and the thick lines correspond to the profile at each selected resolution. Cell size is represented by the rectangles in the background.

From these profiles, one can see that the final volume can be over- or underestimated, depending on the size of the cell, the size of the landforms and the position of the cell with reference to the landforms. Considering the resampled DTMs, the profile for $40 \mathrm{~m}$ cells shows a fair agreement with the reference surface and its calculated volume $\left(10.67 \times 10^{6} \mathrm{~m}^{3}\right)$ deviates $0.60 \%$ from the true LiDAR DTM $\left(10.60 \times 10^{6} \mathrm{~m}^{3}\right)$. A cell size of $80 \mathrm{~m}$ gives an underestimation of the volume $\left(10.42 \times 10^{6} \mathrm{~m}^{3},-1.70 \%\right.$ from the reference), while a resolution of $87 \mathrm{~m}$ is sufficient to overestimate the volume $\left(10.97 \times 10^{6} \mathrm{~m}^{3},+3.40 \%\right.$ from the reference $)$. 

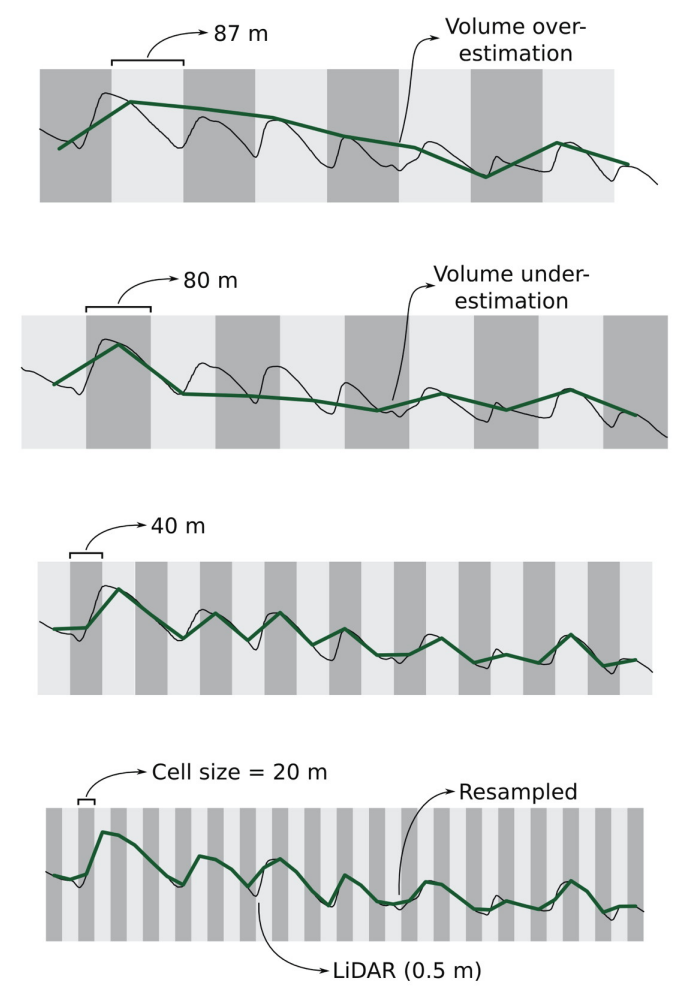

Figure 4. Topographic profiles for selected cell sizes showing effect of under- and overestimation of volume depending on landform size, cell size and position with reference to the landforms. The thin black line corresponds to the profile over the true LiDAR DTM and the thick lines to the profile at each selected resolution. Cell size is represented by the rectangles in the background.

\subsection{SRTM and ASTER GDEM}

Because the study area comprises active dune fields and there is a 10 year difference between SRTM and LiDAR data, the migration rate of these landforms must be considered before comparing calculated volumes. The SRTM Mission was flown on February 2000 (Farr et al., 2007), while ASTER-GDEM was created from optical imagery collected between 2000 and 2007 (Abrams et al., 2010) and the LiDAR data were surveyed in October 2010.

A migration rate of approximately $3 \mathrm{~m} /$ year toward the S-SW is reported by Giannini et al. (2005) for an area immediately north of Garopaba. The time span between SRTM and LiDAR datasets would account for a $30 \mathrm{~m}$ shift in the dune's position, that is, one pixel in SRTM X-SAR and ASTER GDEM and 1/3 pixel in SRTM SIR-C. We do not consider such a difference as an important factor in our analysis.

Table 1 shows the volumes calculated from the LiDAR DTM, SRTM SIR-C, SRTM X-SAR and ASTER GDEM, as well as the differences between these products and the reference LiDAR data.

The deviation of SRTM SIR-C data $(90 \mathrm{~m})$ from the LiDAR DTM was of $-5.06 \%$ for the Garopaba dune field and of $+5.46 \%$ for the Itapirubá dune field. SRTM X-SAR $(30 \mathrm{~m})$ presented a higher variability, deviating $+9.79 \%$ at Garopaba and $+4.08 \%$ at Itapirubá, while ASTER GDEM $(30 \mathrm{~m})$ had the highest deviation range, from $+36.59 \%$ at Garopaba and only $+0.32 \%$ at Itapirubá.

Topographic profiles for the Garopaba (Fig. 5) and Itapirubá (Fig. 6) dune fields provide a visual comparison between the original LiDAR DTM, a DTM resampled to $90 \mathrm{~m}$ and SRTM SIR-C (Figs. 5A,6A), as well as between SRTM X-SAR and ASTER GDEM (Figs. 5B,6B). 
Table 1. Volumes calculated from LiDAR data, SRTM (SIR-C and X-SAR) and ASTER GDEM.

\begin{tabular}{lll}
\hline \multirow{2}{*}{ Data source } & \multicolumn{2}{c}{ Dune field volume $\left(\mathrm{m}^{3}\right)$} \\
\cline { 2 - 3 } & Garopaba & Itapirubá \\
\hline LiDAR $(0.5 \mathrm{~m})$ & $10.60 \times 10^{6}$ & $15.65 \times 10^{6}$ \\
\hline SRTM SIR-C $(90 \mathrm{~m})$ & $10.07 \times 10^{6}$ & $16.51 \times 10^{6}$ \\
Deviation & $-5.06 \%$ & $5.46 \%$ \\
\hline SRTM X-SAR $(30 \mathrm{~m})$ & $11.64 \times 10^{6}$ & $16.29 \times 10^{6}$ \\
Deviation & $9.79 \%$ & $4.08 \%$ \\
\hline ASTER GDEM $(30 \mathrm{~m})$ & $14.49 \times 10^{6}$ & $15.70 \times 10^{6}$ \\
Deviation & $36.59 \%$ & $0.32 \%$ \\
\hline
\end{tabular}

In Fig. 5A, in the Southwest area of the Garopaba dune field (left side of plot), SRTM SIR-C overestimates the landforms, while in the Northeast (right side), where the altitude is very low, it underestimates them, likely because of interference with the radar signal due to the presence of water. In Fig. 5B, the SRTM X-SAR shows a strong noise component, with altitude values ranging from $+60 \mathrm{~m}$ to $-22 \mathrm{~m}$ and a poor representation of the topography. The ASTER GDEM data proved to be consistently above the reference topography. This could be due to the lack of bias elevation correction to a common reference base in the GDEM processing chain (Reuter et al., 2009).
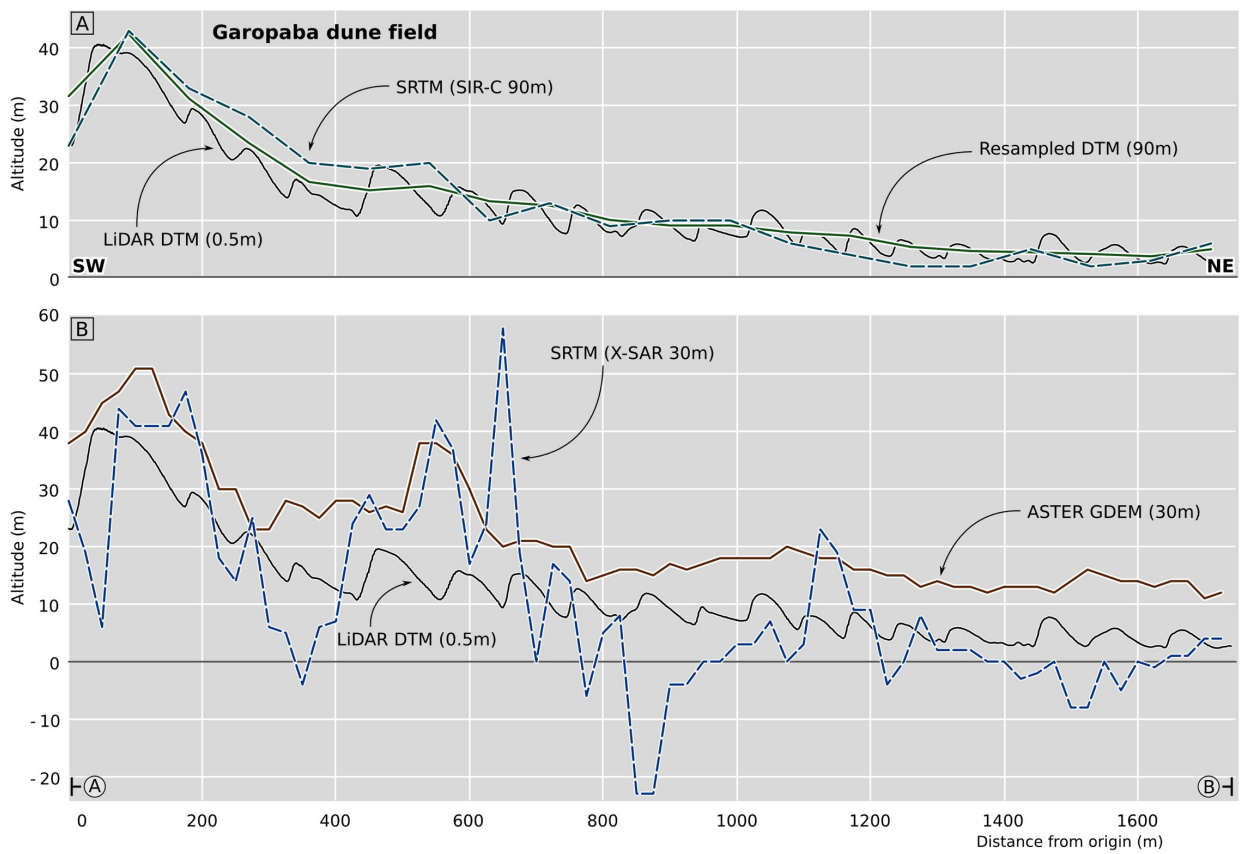

Figure 5. Topographic profile A-B over the Garopaba dune field. In both plots, thin black line represents the LiDAR DTM at $0.5 \mathrm{~m}$ resolution. Upper plot show profiles for SIR-C SRTM and the resampled DTM, both at $90 \mathrm{~m}$ resolution. Lower plot shows data for ASTER-GDEM and X-SAR SRTM, both at $30 \mathrm{~m}$ resolution. 
Profiles for the Itapirubá dune field show that SRTM SIR-C (Fig. 6A) presents a general representation of the topography, with a tendency of overestimation of elevation, more clear in the central area. In this case, the ASTER GDEM (Fig. 6B) provides a good picture of the topography, but the SRTM X-SAR still has a strong noise component.
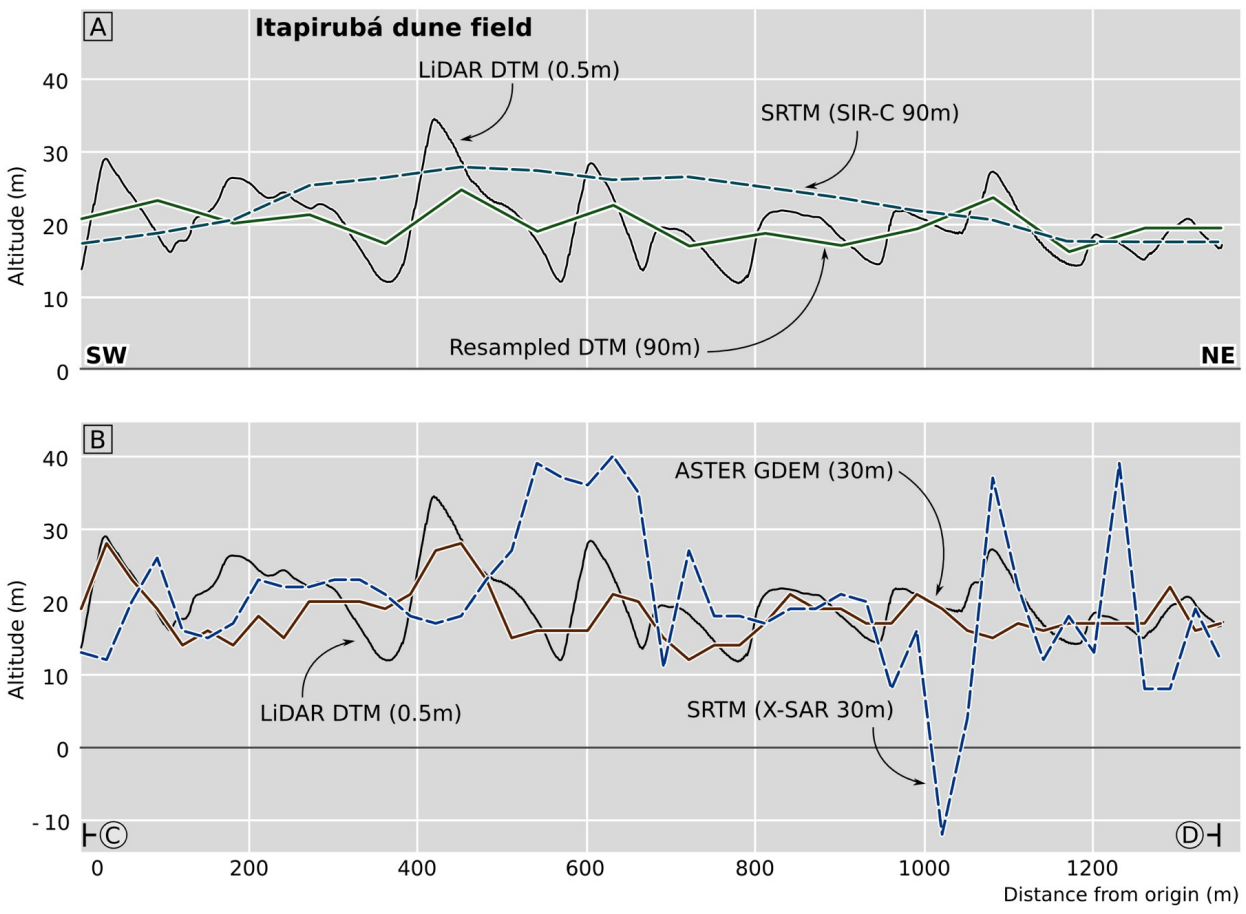

Figure 6. Topographic profile C-D over the Itapirubá dune field. In both plots, thin black line represents the LiDAR DTM at $0.5 \mathrm{~m}$ resolution. Upper plot show profiles for SIR-C SRTM and the resampled DTM, both at $90 \mathrm{~m}$ resolution. Lower plot shows data for ASTER-GDEM and X-SAR SRTM, both at $30 \mathrm{~m}$ resolution.

\section{Discussions and Conclusions}

In this work, the analysis of volume variation with cell size showed a fluctuation of calculated volume values from the reference LiDAR DTM, instead of a simple increasing or decreasing behavior. This can be explained by a random factor between the size of the cell, the size of the landforms and the position of the cell with reference to the landforms, where a small change in cell size can lead to an under- or overestimation of the volume.

An optimal cell size of $20 \mathrm{~m}$ for the Garopaba dune field could be interpreted from the plots in Fig. 2 because this value represents a break point, after which deviation from the reference DTM becomes larger and starts to fluctuate. From the plots of Fig.3, however, one could interpret an optimal size of $40 \mathrm{~m}$, after which both RMSE and R-squared for the LiDAR DTM drop more rapidly. The volumes for the Itapirubá dune field show steady behavior up to 25-30 m (Fig.2B), but the RMSE and R-squared for the LiDAR DTM start dropping only after $50 \mathrm{~m}$.

The size of the landforms must also be considered. In the Garopaba dune field, despite an altitude of approximately $40 \mathrm{~m}$ at its Southwest area (left side of plots in Fig. 5), which could be related to the paleotopography, the height of dunes remains under $10 \mathrm{~m}$. In the Itapirubá dune field, dunes exceed $20 \mathrm{~m}$ in height (Fig. 6).

Although the volume of dune fields is an important variable in numerical simulations to study dune field dynamics, it is hard to determine in a fast and inexpensive way considering the existence of hundreds of dune fields along the Brazilian coast. The high cost of LiDAR surveys is still a barrier to this type of data, especially if one intends to study large areas such as desert dune fields. 
Numerical models are necessary to study the evolution of aeolian dune fields whose development occurs over a timescale of hundreds to millions of years (Livingstone et al., 2010; Vermeesch et al., 2010) because this timescale is beyond observational data. Numerical simulations address variations of the dune field properties (volume, area, etc.) over time spans from days to hundreds or million of years. In such scenarios, a fluctuation in sand volume of $5.5 \%$ would be greater than that expected for short periods (days to years), but not greater than that expected for longer periods of time (hundreds to millions of years) (Sawakuchi, 2006).

With a deviation of volume from the LiDAR DTM of around $+/-5.5 \%$ for both dune fields, SRTM SIR-C (90 m resolution) is a viable source for volume values of dune fields. We also expect this deviation to decrease as the size of dunes and dune field volume increases, as suggested by the comparison between the Garopaba and Itapirubá dune fields.

The ASTER GDEM still generates some controversy in regard to its usefulness. Although it has been found useful in the study of large aeolian landforms (Bubenzer and Bolten, 2008; Hayakawa et al., 2008; Hugenholtz and Barchyn, 2010), Reuter et al. (2009) note that the GDEM product should not be used in terrain analysis at a $30 \mathrm{~m}$ resolution, and Miliaresis and Paraschou (2011) stress the importance of the number of scenes (stack number) used to derive the DEMs, and how vertical accuracy could be elevation- and slope-dependent. In our case, ASTER GDEM data for the Garopaba dune field proved to be consistently above the reference topography, resulting in a deviation of more than $35 \%$ from the reference data, which could be related to unresolved issues in the GDEM processing chain. We also note that the Garopaba and Itapirubá dune fields are relatively small landforms if compared to huge desert fields, such as the Namib dune field where the ASTER data proved to be reliable estimates of sand volume (Bullard et al., 2011).

The SRTM X-SAR data presented a strong noise component and very poor representation of the landforms in the Garopaba dune field. According to Eineder et al. (2001), noise in the $30 \mathrm{~m}$ scale for the X-SAR SRTM is due to thermal effects and should be in the $\pm 4 \mathrm{~m}$ range, but in Fig 5 , the X-SAR elevation ranges from $+60 \mathrm{~m}$ to $-22 \mathrm{~m}$. We believe these issues could be related to radar shadowing in the steep Southwest-facing slopes of the dunes (Strozzi et al., 2003; Ludwig and Schneider, 2006).

The strong difference in the behavior of the SRTM X-SAR between the dune fields, with large deviations from the LiDAR DTM at Garopaba and only small differences at Itapirubá, could be attributed to the geometry of the dune fields, where the Garopaba landforms favor radar shadowing effects, while the errors of the ASTER GDEM show the need for attention when working with such data. A simple comparison to 3-arcsec SRTM data using topographic profiles is recommended prior to analysis.

The high periodicity and geometry of these aeolian landforms may have influenced the results we obtained. Other more random landscape configurations may present a different behavior, and we expect to test such a hypothesis in future studies.

\section{Acknowledgements}

This study was supported by Brazil's State of São Paulo Research Foundation Grant FAPESP \#2009/17675-5 to Carlos Grohmann. An earlier version of this study was presented at the Geomorphometry2011 Conference held in Redlands, California (USA). We appreciate the support given by Geoid Laser Mapping during field work and data processing. We are thankful to Vinícius Ribau Mendes for his help with field work and to the anonymous reviewers for their criticism and suggestions which helped to improve this paper. SRTM X-SAR DEM @DLR/ASI 2011. ASTER GDEM is a product of METI and NASA. This is a GEO-SEDex contribution ( ${ }^{\circ}$ 001), with institutional support of the University of So Paulo (PrPesq). 


\section{References}

Abrams, M., Bailey, B., Tsu, H., Hato, M., 2010. The ASTER Global DEM. Photogrammetric Engineering and Remote Sensing 76, 344-348.

Angulo, R., Lessa, G., Souza, M., 2006. A critical review of mid-to late-Holocene sea-level fluctuations on the eastern Brazilian coastline. Quaternary Science Reviews 25, 486-506.

Bourke, M.C., Lancaster, N., Fenton, L.K., Parteli, E.J., Zimbelman, J.R., Radebaugh, J., 2010. Extraterrestrial dunes: An introduction to the special issue on planetary dune systems. Geomorphology 121, $1-14$.

Brovelli, M.A., Cannata, M., 2004. Digital terrain model reconstruction in urban areas from airborne laser scanning data: the method and an example for Pavia (northern Italy). Computers \& Geosciences 30, 325-331.

Brovelli, M.A., Cannata, M., Longoni, U.M., 2004. LIDAR Data Filtering and DTM Interpolation Within GRASS. Transactions in GIS 8, 155-174.

Bubenzer, O., Bolten, A., 2008. The use of new elevation data (SRTM/ASTER) for the detection and morphometric quantification of Pleistocene megadunes (draa) in the eastern Sahara and the southern Namib. Geomorphology 102, 221-231.

Bullard, J.E., White, K., Livingstone, I., 2011. Morphometric analysis of aeolian bedforms in the Namib Sand Sea using ASTER data. Earth Surface Processes and Landforms 36, 1534-1549.

Butler, H., Loskot, M., Vachon, P., Vales, M., Warmerdam, F., 2011. libLAS: ASPRS LAS LiDAR Data Toolkit. Last access:15/Feb/2011.

Clemmensen, L.B., Bjørnsen, M., Murray, A., Pedersen, K., 2007. Formation of aeolian dunes on Anholt, Denmark since AD 1560: A record of deforestation and increased storminess. Sedimentary Geology 199, $171-187$.

Earth Remote Sensing Data Analysis Center, 2009. ASTER Global Digital Elevation Model. (accessed 05 December, 2011).

Eineder, M., Breit, H., Adam, N., Holzner, J., Suchandt, S., Rabus, B., 2001. SRTM X-SAR calibration results, in: Geoscience and Remote Sensing Symposium, 2001. IGARSS '01. IEEE 2001 International, pp. 748 -750 vol.2.

Farr, T.G., Rosen, P.A., Caro, E., Crippen, R., Duren, R., Hensley, S., Kobrick, M., Paller, M., Rodriguez, E., Roth, L., Seal, D., Shaffer, S., Shimada, J., Umland, J., Werner, M., Oskin, M., Burbank, D., Alsdorf, D., 2007. The Shuttle Radar Topography Mission. Review of Geophysics 45, RG2004.

Fenton, L.K., Hayward, R.K., 2010. Southern high latitude dune fields on Mars: Morphology, aeolian inactivity, and climate change. Geomorphology 121, $98-121$.

Fryberger, S.G., Dean, G., 1979. A Study of Global Sand Seas. U.S. Geological Survey. volume Prof. Paper 1052. chapter Dune forms and wind regime. pp. 137-169.

Giannini, P.C.F., Assine, M.L., Barbosa, L.M., Barreto, A.M.F., Carvalho, A.M., Claudino Sales, V., Maia, L.P., Martinho, C.T., Peulvast, J.P., Sawakuchi, A.O., Tomazelli, L.J., 2005. Dunas eólicas costeiras e interiores [Coastal and interior aeolian dunes], in: Souza, C.R.G., Suguio, K., Oliveira, P.E., Oliveira, A.M. (Eds.), Quaternário do Brasil [Brazil's Quaternary]. Holos, Abequa, ANP, FAPESP, IG, UnG., pp. 235-257.

Giannini, P.C.F., Sawakuchi, A.O., Martinho, C.T., Tatumi, S.H., 2007. Eolian depositional episodes controlled by Late Quaternary relative sea level changes on the Imbituba-Laguna coast (southern Brazil). Marine Geology 237, 143-168.

GRASS Development Team, 2009. Geographic Resources Analysis Support System (GRASS GIS) Software, Version 6.4.0. Http://grass.osgeo.org, [accessed 05 December 2011].

Grohmann, C.H., Smith, M.J., Riccomini, C., 2010. Multiscale Analysis of Topographic Surface Roughness in the Midland Valley, Scotland. Geoscience and Remote Sensing, IEEE Transactions on 49, 1200-1213.

Hayakawa, Y.S., Oguchi, T., Lin, Z., 2008. Comparison of new and existing global digital elevation models: ASTER G-DEM and SRTM-3. Geophysical Research Letters 35, L17404.

Hayward, R., Mullins, K., Fenton, L., Hare, T., Titus, T., Bourke, M., Colaprete, A., Christensen, P., 2007. Mars global digital dune database and initial science results. Journal of Geophysical Research 112, E11007.

Hesp, P., Abreu de Castilhos, J., Miot da Silva, G., Dillenburg, S., Martinho, C.T., Aguiar, D., Fornari, M., Fornari, M., Antunes, G., 2007. Regional wind fields and dunefield migration, southern Brazil. Earth Surface Processes and Landforms 32, 561-573.

Hesp, P.A., Giannini, P.C.F., Martinho, C.T., Silva, G.M.D., Neto, N.E., 2009. The Holocene Barrier Systems of the Santa Catarina Coast, Southern Brazil, in: Dillenburg, S.R., Hesp, P.A. (Eds.), Geology and Geomorphology of Holocene Coastal Barriers of Brazil, Lecture Notes in Earth Sciences. Springer Berlin / Heidelberg. volume 107, pp. 93-133.

Hinthorne, J., 1988. r.volume GRASS-GIS module. [accessed 05 December 2011].

Hugenholtz, C.H., Barchyn, T.E., 2010. Spatial analysis of sand dunes with a new global topographic dataset: new approaches and opportunities. Earth Surface Processes and Landforms 35, 986-992.

Lancaster, L., 2008. Desert dunes dynamics and development: insights from luminescence dating. Boreas 37, $559-573$.

Levin, N., 2011. Climate-driven changes in tropical cyclone intensity shape dune activity on Earth's largest sand island. Geomorphology 125, $239-252$.

Livingstone, I., Bristow, C., Bryant, R.G., Bullard, J., White, K., Wiggs, G.F., Baas, A.C., Bateman, M.D., Thomas, D.S., 2010. The Namib Sand Sea digital database of aeolian dunes and key forcing variables. Aeolian Research 2, $93-104$.

Livingstone, I., Wiggs, G.F., Weaver, C.M., 2007. Geomorphology of desert sand dunes: A review of recent progress. Earth-Science Reviews 80, 239 - 257.

Ludwig, R., Schneider, P., 2006. Validation of digital elevation models from SRTM X-SAR for applications in hydrologic modeling. ISPRS Journal of Photogrammetry and Remote Sensing 60, $339-358$. 
Martinho, C.T., Giannini, P.C.F., Sawakuchi, A.O., Hesp, P.A., 2006. Morphological and depositional facies of transgressive dunefields in the Imbituba-Jaguaruna region, Santa Catarina State. Journal of Coastal Research SI39, 143-168

Martinho, C.T., Hesp, P.A., Dillenburg, S.R., 2010. Morphological and temporal variations of transgressive dunefields of the northern and mid-littoral Rio Grande do Sul coast, Southern Brazil. Geomorphology 117,14 32 .

Miliaresis, G.C., Paraschou, C.V.E., 2011. An evaluation of the accuracy of the ASTER GDEM and the role of stack number: a case study of Nisiros Island, Greece. Remote Sensing Letters 2, 127-135.

Neteler, M., Mitasova, H., 2008. Open Source GIS : A GRASS GIS Approach, Third Edition (The International Series in Engineering and Computer Science). volume 773. Springer, New York.

Radebaugh, J., Lorenz, R., Lunine, J., Wall, S., Boubin, G., Reffet, E., Kirk, R., Lopes, R., Stofan, E., Soderblom, L., Allison, M., Janssen, M., Paillou, P., Callahan, P., Spencer, C., the Cassini Radar Team, 2008. Dunes on Titan observed by Cassini Radar. Icarus 194, 690 - 703.

Reuter, H.I., Neison, A., Strobl, P., Mehl, W., Jarvis, A., 2009. A first assessment of ASTER GDEM tiles for absolute accuracy, relative accuracy and terrain parameters, in: Geoscience and Remote Sensing Symposium,2009 IEEE International,IGARSS 2009, pp. V-240 -V-243.

Sawakuchi, A.O., 2006. Morfometria e simulação numérica de campos de dunas costeiros: estudo baseado em exemplos brasileiros [Morphology and numerical simulation of coastal dune fields: study based on Brazilian examples]. Ph.D. thesis. Instituto de Geociências, Universidade de São Paulo, São Paulo.

Sawakuchi, A.O., Kalchgruber, R., Giannini, P.C.F., Nascimento Jr, D.R., Guedes, C.C.F., Umisedo, N.K., 2008. The development of blowouts and foredunes in the Ilha Comprida barrier (Southeastern Brazil): the influence of Late Holocene climate changes on coastal sedimentation. Quaternary Science Reviews 27, 2076 - 2090.

Short, A.D., 1988. Holocene coastal dune formation in southern australia: A case study. Sedimentary Geology 55, $121-142$.

Singhvi, A., Williams, M., Rajaguru, S., Misra, V., Chawla, S., Stokes, S., Chauhan, N., Francis, T., Ganjoo, R., Humphreys, G., 2010. A 200ka record of climatic change and dune activity in the Thar Desert, India. Quaternary Science Reviews 29, 3095 - 3105.

Strozzi, T., Wegmuller, U., Wiesmann, A., Werner, C., 2003. Validation of the X-SAR SRTM DEM for ERS and JERS SAR geocoding and 2-pass differential interferometry in alpine regions, in: Geoscience and Remote Sensing Symposium, 2003. IGARSS'03. Proceedings. 2003 IEEE International, IEEE. pp. 109-111.

Tsoar, H., Levin, N., Porat, N., Maia, L.P., Herrmann, H.J., Tatumi, S.H., Claudino-Sales, V., 2009. The effect of climate change on the mobility and stability of coastal sand dunes in Cear State (NE Brazil). Quaternary Research 71, $217-226$.

Vermeesch, P., Fenton, C.R., Kober, F., Wiggs, G.F.S., Bristow, C.S., Xu, S., 2010. Sand residence times of one million years in the Namib Sand Sea from cosmogenic nuclides. Nature Geoscience 3, 862-865.

Wang, X., Dong, Z., Zhang, J., Chen, G., 2002. Geomorphology of sand dunes in the Northeast Taklimakan Desert. Geomorphology 42, $183-195$.

Wintle, A., 1993. Luminescence dating of aeolian sands: an overview. Geological Society of London, Special Publications 72, 49-58. 